\title{
Characterization of aqueous silver nitrate solutions for leakage tests
}

José Ferreira COSTA 1 , Walter Luiz SIQUEIRA ${ }^{2}$, Alessandro Dourado LOGUERCIO ${ }^{3}$, Alessandra REIS ${ }^{3}$, Elizabeth de OLIVEIRA ${ }^{4}$, Cláudia Maria Coelho ALVES ${ }^{1}$, José Roberto de Oliveira BAUER ${ }^{1}$, Rosa Helena Miranda GRANDE ${ }^{5}$

1- DDS, PhD, Assistant Professor, Department of Operative Dentistry, Dental School, Federal University of Maranhão, São Luiz, MA, Brazil.
2- DDS, PhD, Assistant Professor, Schulich School of Medicine \& Dentistry, University of Western Ontario, London, ON, Canada.
3- DDS, PhD, Adjunctive Professors, Department of Restorative Dentistry, State University of Ponta Grossa, Ponta Grossa, PR, Brazil.
4- Professor, Institute of Chemistry, University of São Paulo, São Paulo, SP, Brazil.
5- DDS, PhD, Associate Professor, Department of Dental Materials, Dental School, University of São Paulo, São Paulo, SP, Brazil.

Corresponding address: - Rosa Helena Miranda Grande - Avenida Prof. Lineu Prestes, 2227 - Cidade Universitária - 05508-900 - São Paulo - SP - Phone/ Fax: +55-11-3091-7840 - e-mail:grande@usp.br

Received: June 4, 2009 - Modification: October 9, 2009 - Accepted: February 16, 2010

\section{ABSTRACT}

$\mathrm{O}$ bjectives: To determine the $\mathrm{pH}$ over a period of $168 \mathrm{~h}$ and the ionic silver content in various concentrations and post-preparation times of aqueous silver nitrate solutions. Also, the possible effects of these factors on microleakage test in adhesive/resin restorations in primary and permanent teeth were evaluated. Material and Methods: A digital $\mathrm{pHmeter}$ was used for measuring the $\mathrm{pH}$ of the solutions prepared with three types of water (purified, deionized or distilled) and three brands of silver nitrate salt (Merck, Synth or Cennabras) at $0,1,2,24,48,72,96$ and $168 \mathrm{~h}$ after preparation, and storage in transparent or dark bottles. Ionic silver was assayed according to the post-preparation times $(2,24,48,72,96,168 \mathrm{~h})$ and concentrations $(1,5,25,50 \%)$ of solutions by atomic emission spectrometry. For each sample of each condition, three readings were obtained for calculating the mean value. Class $V$ cavities were prepared with enamel margins on primary and permanent teeth and restored with the adhesive systems OptiBond FL or OptiBond SOLO Plus SE and the composite resin Filtek Z-250. After nail polish coverage, the permanent teeth were immersed in $25 \%$ or $50 \% \mathrm{AgNO}_{3}$ solution and the primary teeth in $5 \%$ or $50 \% \mathrm{AgNO}_{3}$ solutions for microleakage evaluation. ANOVA and the Tukey's test were used for data analyses $(\alpha=5 \%)$. Results: The mean $\mathrm{pH}$ of the solutions ranged from neutral to alkaline (7.9 2.2 to $11.8 \pm 0.9)$. Mean ionic silver content differed depending on the concentration of the solution ( $4.75 \pm 0.5$ to $293 \pm 15.3 \mathrm{ppm})$. In the microleakage test, significant difference was only observed for the adhesive system factor $(p=0.000)$. Conclusions: Under the tested experimental conditions and based on the obtained results, it may be concluded that the aqueous $\mathrm{AgNO}_{3}$ solutions: have neutral/alkaline $\mathrm{pH}$ and service life of up to $168 \mathrm{~h}$; the level of ionic silver is proportional to the concentration of the solution; even at $5 \%$ concentration, the solutions were capable of indicating loss of marginal seal in the composite restorations; the 3-step conventional adhesive system had better performance regarding microleakage in enamel on primary and permanent teeth.

Key words: Silver nitrate. Dental leakage. Adhesives.

\section{INTRODUCTION}

The dye penetration technique is one of the most used methods for assessing marginal seal ${ }^{1,14}$ because it allows penetration of the substance to be verified in contrasting colors at the tooth-restoration interface, without requiring a chemical reaction or the use of radioactive materials ${ }^{28,29}$. In spite of the variety of dyes mentioned in the literature ${ }^{7}$, several authors have used chemical tracers ${ }^{4,14,15,19,30}$, such as $50 \%$ silver nitrate $(\mathrm{w} / \mathrm{v})$ with special frequency in microleakage assays, using different immersion times of specimens in the agent and different times to reveal the silver ${ }^{3,7,19}$. The amount and distribution of silver show the extent of damage at the material/ tooth interface, which can be measured by using 
various micro-investigation techniques 6,12,28,29,30. Considering the penetration capacity of the silver nitrate solution, its use is considered a very severe test $^{19}$ because the diameter of the silver ion is very small $(0.059 \mathrm{~nm})$ when compared to the mean size of a bacteria $(0.5-1.0 \mu \mathrm{m})^{13}$.

Silver nitrate has been extensively used for analyzing the degradation at tooth/material interface, since Sano, et al. ${ }^{21}$ (1995) detected the presence of silver nitrate in the hybrid layer, calling the phenomenon nanoleakage. Several authors ${ }^{15,16,26}$ adopted silver nitrate as a tracer for nanoleakage analysis because of its contrast quality observed in microleakage. By its use, it was possible to verify that there is discrepancy between the depth of the demineralized zone and monomer diffusion ${ }^{27}$, as a result of the presence of water around the collagen fibrils ${ }^{21}$.

In nanoleakage tests, the $\mathrm{pH}$ of silver nitrate solutions, considered acid (4.3), would be disadvantageous, since the samples remain immersed for a long period $(24 \mathrm{~h})^{12,15}$. Therefore, some authors developed buffered solutions ${ }^{25}$ and others indicated the use of a $5 \%$ silver methenamine solution $(\mathrm{pH}$ $8.1)^{9}$. However, in spite of their relevance, some of the variables ${ }^{15,16,25}$ are not clear.

The aims of this study were to determine the $\mathrm{pH}$ over a period of $168 \mathrm{~h}$ and the ionic silver content in various concentrations and post-preparation times of aqueous silver nitrate solutions, as well as to verify the possible effects of these factors on microleakage test in class $\mathrm{V}$ composite restorations placed in primary and permanent molars.

\section{MATERIAL AND METHODS}

\section{pH analysis}

In the first phase, the alterations in $\mathrm{pH}$ of $50 \%$ $(\mathrm{w} / \mathrm{v})$ aqueous silver nitrate solutions, stored for up to $168 \mathrm{~h}$, were observed. Water used as solvent for the silver nitrate salt $\left(\mathrm{AgNO}_{3}\right)$, was treated in three ways: 1 ) by distillation (Fisatom Equipamentos Científicos, São Paulo, SP, Brazil), 2) by deionization (Permution; Krieger Cia Ltda, Curitiba, PR, Brazil), or 3) by purification (Milli-Q; Millipore Corp, Billerica, MA, USA). Three brands of silver nitrate salt were selected: 1) Merck (Merck \& Co Inc, Darmstadt, HE, Germany), 2) Synth (Labsynth, Diadema, SP, Brazil), or 3) Cennabras (Cennabras Ind \& Com Ltda, Guarulhos, SP, Brazil). Two types of bottles were used (transparent or dark).

All bottles were coded with regard to the conditions of the experiment ${ }^{18}$ and 3 replicas per condition were obtained to calculate the mean value. The solutions were prepared, $\mathrm{pH}$ readings were taken, and the bottles were stored in an acclimatized room under conditions of fixed temperature $\left(25^{\circ} \mathrm{C}\right)$ and relative humidity $(60 \%)$.
The silver nitrate salt $(2.5 \mathrm{~g} \pm 0.01 \mathrm{~g})$ was weighed in an analytical balance Adventurer Series (OHAUS Corp, Pine Brook, NJ, USA), $5.0 \mathrm{~mL}$ of water were added and the was beaker placed on a magnetic agitator MT2 (Amicon Div; WR Grace \& Co, Beverly, MA, USA), with the speed (rpm) at level 4, for 3 min to homogenize the solution. A digital pHmeter (Digimed - DM22; ServMed Analítica, Guarulhos, SP, Brazil), calibrated with standard solutions of $\mathrm{pH} 4.0$ and 6.9 , was used to take the $\mathrm{pH}$ readings. The $\mathrm{pH}$ readings were taken immediately, and after $1,2,24$, $48,72,96$ and $168 \mathrm{~h}$.

\section{Ionic silver analysis}

The ionic silver was measured considering the post-preparation age $(2,24,48,72,96,168 \mathrm{~h})$ and concentration of solutions $(1 \%, 5 \%, 25 \%$ and $50 \%$ ), by means of the atomic emission spectrometry (Spectroflame; Spectro Analytical Instruments, Kleve, NW, Germany). All bottles were coded according to the conditions of the experiment ${ }^{24}$ and 3 readings per condition were taken to calculate the mean value.

\section{Microleakage test}

To analyze the influence of the adhesive system, post-preparation time of the solution and concentration of solutions on the microleakage tests, Class $\mathrm{V}$ resin restorations were made in permanent teeth (64 third molars) and primary teeth (20 molars). The teeth were obtained by donation, after the research project had been approved by the Research Ethics Committee of FOUSP (No. 151/2004).

The teeth were stored in $0.5 \%$ chloramine at $4^{\circ} \mathrm{C}$ for 7 days, cleaned and kept in distilled water until the experimental stage. Then, they were cleaned with pumice and ultrasonicated with distilled water for 5 min (Thornton Eletrônica Ltda, Vinhedo, SP, Brazil).

The roots were sealed with 2 layers of a fast drying nail polish (Maybelline; L'Oréal, New York, NY, USA), embedded in plastic cylinders with acrylic resin, up to the height of the cervical portion. In each tooth, two class $\mathrm{V}$ cavities were prepared ${ }^{3}$, with standardized dimensions of $4 \mathrm{~mm}$ (mesiodistal width), $2 \mathrm{~mm}$ (occlusogingival height) and $2 \mathrm{~mm}$ (depth) on the buccal and lingual surfaces. Cylindrical diamonds burs (FG 3100; KG Sorensen Ind. \& Com. Ltda, Barueri, SP, Brazil) under constant water spray cooling were used. The cavosurface angle of preparation was entirely located in enamel, without beveling ${ }^{21}$, since one of the goals was to analyze the marginal seal $2,5,10,14,22,24$. The methodology for the primary teeth was the same as described for the permanent teeth.

The permanent teeth were divided into 8 groups $(n=8)$, considering two concentrations of silver nitrate solutions ( 25 and $50 \%$ ), two post-preparation times of the solutions ( 2 and $72 \mathrm{~h}$ ) and two adhesive systems. The primary teeth were divided into 4 
groups $(n=5)$, considering two concentrations of solutions ( 5 and $50 \%$ ) prepared $2 \mathrm{~h}$ before and two adhesive systems.

The adhesive-restorative procedures were performed in an acclimatized room at a temperature of $25^{\circ} \mathrm{C}$ and relative humidity of $60 \%$, by a single operator. After drying, the cavities were remoistened $^{20}$ with $2 \mu \mathrm{L}$ of water applied with an automatic pipette (Socorex ISBA S.A, Lausanne, VD, Switzerland), and the adhesive systems were applied in accordance with the manufacturer's specifications (Figure 1). The cavities were restored with Filtek Z-250 (3M ESPE, St. Paul, MN, USA) in three horizontal increments, each one light-activated for 40 s (Jet Lite 4000 Plus; J. Morita Corp, Suita, OSA, JPN).

The specimens were stored in distilled water at $37^{\circ} \mathrm{C}$ for $24 \mathrm{~h}^{1,4,15,23}$ in a humidifier incubator (Nova Ética Ind \& Com Ltda, Vargem Grande Paulista, $\mathrm{SP}$, Brazil). After this period, each restoration was finished with aluminum oxide disks (Sof-Lex; 3M ESPE) of different grain sizes (medium, fine, and extra-fine), under constant water cooling ${ }^{17}$.

The entire crown of each washed and dried specimen was covered with two layers of the nail polish, leaving exposed only a window of about 1 $\mathrm{mm}$ around each restoration.

After immersion in the silver nitrate solutions for $2 \mathrm{~h}$, the specimens were washed, immersed in a photographic developer (Eastman; Kodak Co,
Rochester, NY, USA) for $8 \mathrm{~h}$ under fluorescent light, and then abundantly washed under running water ${ }^{4,19}$.

Afterwards, the specimens were sectioned parallel to the long axis in the mesiodistal direction, to obtain two halves with a restoration in each of them, which were then sectioned two times in the cervico-occlusal direction, with diamond saws fitted to a hard tissue cutting machine (Isomet 1000; Buehler Ltd, Lake Bluff, IL, USA).

Three sections with 4 surfaces of each restoration per tooth were obtained for visual analysis. To make a linear quantification of the tracer penetration at the bond interfaces, the images of the 4 surfaces of each restoration were captured with a digital camera (Hyper HAD; Sony Corp, Tokyo, TYO, JPN) coupled to a stereoscopic loupe (Citoval 2; Carls Zeiss Corp, Oberkochen, BW, Germany), using Vidcap 32 software. Digital images were generated at 20x magnification. Cavity depth was measured $(\mathrm{mm})$ at the gingival and occlusal walls as well as the depth of tracer penetration, by means of the IMAGELAB 2000 software, developed at LIDO (Computational Laboratory Dedicated to Dentistry at FOUSP). A percentage mean value was defined for each restoration.

Data were analyzed by ANOVA and Tukey's test $(\alpha=5 \%)$ to determine the main effects and interactions between the factors of interest ${ }^{18}$.

\begin{tabular}{|c|c|c|c|}
\hline Material, Manufacturer and Lot & Presentation & Basic Composition & Application \\
\hline $\begin{array}{c}\text { Adhesive system OptiBond FL } \\
\text { (Kerr SDS, Orange, CA, USA) } \\
301320\end{array}$ & $\begin{array}{l}\text { Primer } \\
\text { Bond }\end{array}$ & $\begin{array}{c}\text { HEMA, PAMA, GPDM, camphoroquinone, } \\
\text { alcohol, water } \\
\text { Bis-GMA, HEMA, GPDM, camphoroquinone, } \\
\text { glycerol, dimethacrylate } \\
\text { Filler: } 48 \% \text { weight (Ba-Al silicate borum, } \\
\text { pyrolytic silicone, disodium silicate hexafluoride) }\end{array}$ & $\begin{array}{c}a, b, c, d, \\
e, f\end{array}$ \\
\hline $\begin{array}{c}\text { Adhesive system OptiBond Solo Plus SE } \\
\qquad \begin{array}{c}\text { (Kerr SDS, Orange, CA, USA) } \\
304947 \text { and } 304198\end{array}\end{array}$ & $\begin{array}{l}\text { Self- etching } \\
\text { primer } \\
\text { Bond }\end{array}$ & $\begin{array}{c}\text { GDN, GPDM, MEHQ, EDMAB, } \\
\text { camphoroquinone } \\
\text { Bis-GMA, HEMA, GDM, GPDM, } \\
\text { camphoroquinone, alcohol } \\
\text { Filler: } 15 \% \text { weight (Ba-Al silicate borum, } \\
\text { pyrolytic silicone, disodium silicate hexafluoride) }\end{array}$ & $\begin{array}{c}\mathrm{b} c, \mathrm{~d}, \mathrm{~g} \\
\mathrm{~h}, \mathrm{i}\end{array}$ \\
\hline $\begin{array}{c}\text { Etching Agent } \\
\text { (Kerr SDS, Orange, CA, USA) } \\
301194\end{array}$ & Gel & $37.5 \%$ phosphoric acid & \\
\hline
\end{tabular}

Sequence of application: a) acid etching of cavity (15 s enamel + $15 \mathrm{~s}$ dentin); b) wash with water (30 s); c) vigorous drying with air; d) wet cavity with water $(2 \mu \mathrm{l})$; e) apply primer rubbing the surface (15 s) and apply light jet of air (5 s); f) uniform application of bond FL in a single layer and light-activation $600 \mathrm{~mW} / \mathrm{cm}^{2}(30 \mathrm{~s}) ; \mathrm{g}$ ) apply self-etching primer SE rubbing the surface lightly (15 s) and apply light jet of air (5 s); h) apply first layer of bond SE rubbing lightly (15 s) and light jet of air (3 $\mathrm{s})$; i) apply second layer of bond SE and light jet of air (3 s) and light-activation $600 \mathrm{~mW} / \mathrm{cm}^{2}(20 \mathrm{~s})$

Figure 1- Material and sequence used in adhesive procedures 


\section{RESULTS}

In the $\mathrm{pH}$ analysis of $50 \%$ solution, there was a statistically significant difference $(p<0.05)$ for the factors salt brand, water purity, bottle type, but there was no difference for the factor post-preparation time (age) of solutions $(\mathrm{p}=0.99)$. The mean $\mathrm{pH}$ was always higher than $7(7.9 \pm 2.2$ to $11.8 \pm 0.9)$, under all of the 18 conditions (Figure 2).

In the analysis of ionic silver in the 5, 25 and 50\% solutions, only silver amount was significantly different $(p<0.01)$, that is, the higher the concentration of the solution the higher the amount of silver. The age of solution and interaction ( $\mathrm{XxC}$ ) showed no significant differences $(p=0.30)$. The mean values are shown in
Figure 3, with variation of $4.75 \pm 0.5$ to $293.5 \pm 15.3$ ppm.

In the microleakage tests, the mean tracer penetration values were calculated according to the adhesive system, concentration and post-preparation time of solutions (Table 1) for permanent teeth. For primary teeth, the mean tracer penetration was calculated according to adhesive and concentration of the solutions (Table 2). Only the factor Adhesive allowed the detection of significant difference (Tables 1 and 2, $\mathrm{p}=0.000$ ). OptiBond FL showed the lowest mean values of penetration, irrespective of concentration or post-preparation time of solutions (Tables 1 and 2).

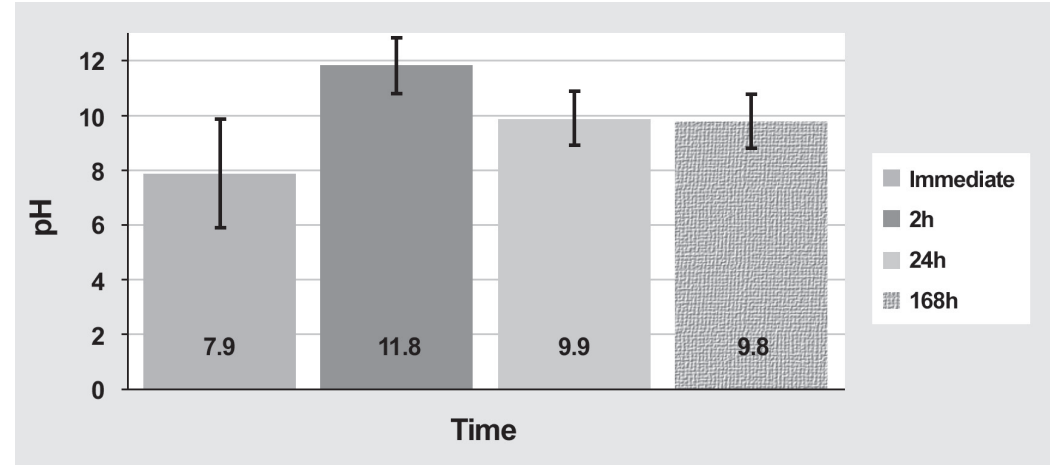

Figure 2- Means and standard deviations of $\mathrm{pH}$ according to the post-preparation times of solutions

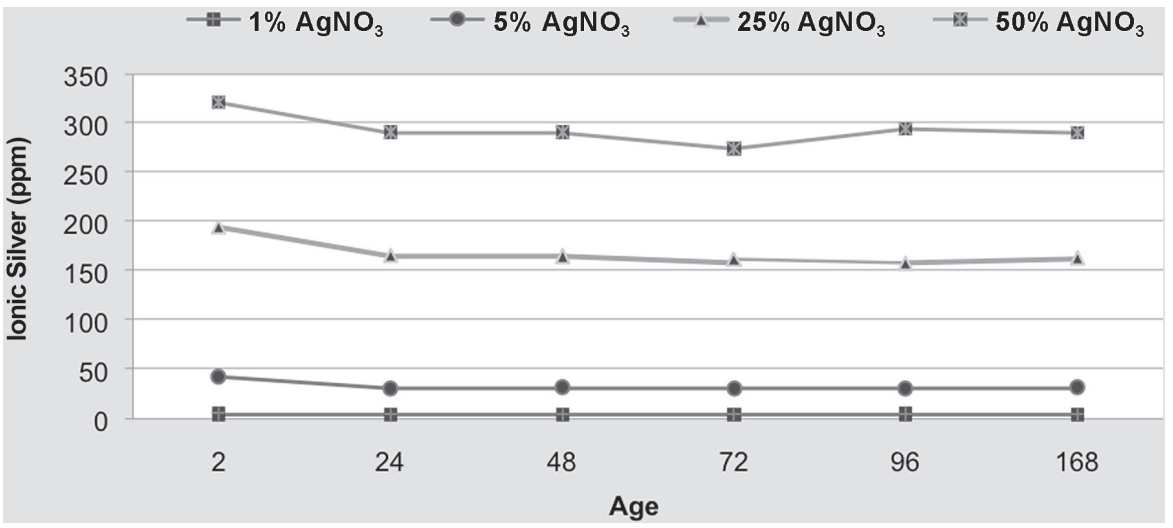

Figure 3- Distribution of the amount of ionic silver in the solutions according to the post-preparation times and concentrations

Table 1- Mean values and standard deviations $(\mathrm{mm})$ of tracer penetration in permanent teeth regarding adhesive systems according to concentration and post preparation time of solutions as well as statistical significance*

\begin{tabular}{|c|c|c|c|c|c|c|c|c|}
\hline \multirow{3}{*}{$\begin{array}{l}\text { Concentration } \\
\text { Time } \\
\text { Adhesive }\end{array}$} & \multicolumn{4}{|c|}{$25 \%$} & \multicolumn{4}{|c|}{$50 \%$} \\
\hline & \multicolumn{2}{|c|}{$2 \mathrm{~h}$} & \multicolumn{2}{|c|}{$72 \mathrm{~h}$} & \multicolumn{2}{|c|}{$2 \mathrm{~h}$} & \multicolumn{2}{|c|}{$72 \mathrm{~h}$} \\
\hline & FL & SE & FL & SE & FL & SE & FL & SE \\
\hline Mean \pm standard deviation & $1.6 \pm 0.4^{a}$ & $1.9 \pm 0.6^{b}$ & $1.2 \pm 0.8^{a}$ & $2.2 \pm 0.4^{b}$ & $1.6 \pm 0.4^{a}$ & $2.2 \pm 0.4^{b}$ & $1.6 \pm 0.3^{a}$ & $2.2 \pm 0.5^{b}$ \\
\hline
\end{tabular}

*Values with same letter are not significantly different ( $p>0.05)$. FL= Optibond FL; SE= Optibond SOLO Plus SE 
Table 2- Mean values $(\mathrm{mm}) \pm$ standard deviations $(\mathrm{SD})$ of tracer penetration in deciduous teeth regarding adhesive systems according to concentration of solutions, as well as, statistical significance*

\begin{tabular}{lccccc}
\hline & \multicolumn{2}{c}{$5 \%$ Concentration } & \multicolumn{2}{c}{$\mathbf{5 0 \%}$ Concentration } \\
Adhesive System & FL & SE & FL & SE \\
\hline Mean \pm SD & $0.038 \pm 0.08^{\mathrm{a}}$ & $0.348 \pm 0.40^{\mathrm{b}}$ & $0.025 \pm 0.04^{\mathrm{a}}$ & $0.428 \pm 0.42^{\mathrm{b}}$ \\
\hline
\end{tabular}

*Values with same letter are not significantly different $(p>0.05)$. FL= Optibond FL; SE= Optibond SOLO Plus SE

\section{DISCUSSION}

The findings of this study showed that the $\mathrm{pH}$ of aqueous silver nitrate solutions ranges from neutral to alkaline; this result will always be found whenever the solvent of the solution is water, a finding that has not been explained in previous studies ${ }^{7,28,29}$.

With the use of silver nitrate in nanoleakage studies and immersion time of $24 \mathrm{~h}^{3,11,25}$, there has been concern about the possible demineralizing effect of the solutions, said to be acid, and this aspect would compromise the results. Nevertheless, the authors who made reference to the acid $\mathrm{pH}$ of silver nitrate solutions ${ }^{9,15,16,25}$ presented no details of their formulation, and some of them did not even mention the term "aqueous". This leads us to suppose that they used nitric acid as the solvent, and consequently obtained solutions with a low $\mathrm{pH}$. Therefore, the results of this study, as regards the acidity of the solutions, are in line with those presented in the literature.

Some authors $9,16,25$ mentioned the possible problems arising from the use of silver nitrate solutions at concentrations as high as $50 \%$ : the need to seal the specimens in order to guarantee that there are no other pathways of silver nitrate penetration, and immersion time of $24 \mathrm{~h}$. Considering the results obtained in this study, it seems that one can use solutions at lower concentrations; it only remains to be verified whether it is really necessary for specimens, in nanoleakage studies, to stay immersed in the solution for $24 \mathrm{~h}$.

Our results corroborate those of $\mathrm{Li}$, Burrow and Tyas $^{15}$ (2003), proving that an aqueous silver nitrate solution at concentrations lower than $50 \%$ ( $25 \%$ or even $5 \%$ ) is capable of providing a satisfactory and reliable standard of leakage in microleakage tests. It was also noted that the age or post-preparation time of the solutions did not cause significant changes in $\mathrm{pH}$, when the assessment was performed within a period of up to $168 \mathrm{~h}$. Although there are no reports in the literature referring to this important feature, the observations made in this study allow researchers to work in a safe and organized way for a longer period of time, providing a certain leeway in performing the tests.

In the analysis of microleakage in Class $V$ cavities prepared in permanent and primary teeth, the results showed that the variables post-preparation time and concentration of the solutions did not interfere in the mean values obtained.

Nevertheless, for the factor Adhesive, ANOVA showed significant differences, and the OptiBond FL showed better performance in comparison with the OptiBond Solo Plus SE, in both permanent and deciduous teeth (Tables 1 and 2 ). The results of this study are similar to those found by Ernst, et al. ${ }^{8}$ (2004) in the enamel cervical margin of Class II restorations, using the OptiBond $\mathrm{FL}$ in comparison with the two-step and one-step self-etching adhesive systems.

In a similar manner, Swanson, et al. ${ }^{24}$ (2008) found significant differences in enamel margins when a total-etch adhesive system was compared with the self-etch in primary and permanent teeth. On the other hand, Silveira de Araújo, et al. ${ }^{22}$ (2006) did not observe any significant difference in the microleakage scores at the enamel margins when total-etch and self-etch adhesive systems were used. Result confirmed by Borges, Matos and Dias ${ }^{5}$ (2007), in class $\mathrm{V}$ restorations with margins in enamel, using total-etch and self-etch adhesives systems. However, Giachetti, et al. ${ }^{10}$ (2008), examining both adhesive protocols, observed that the performance of the materials was dependent on the technique sensitivity and the operator skills.

\section{CONCLUSIONS}

Under the tested experimental conditions and based on the obtained results, it may be concluded that the aqueous silver nitrate solutions: have neutral/ alkaline $\mathrm{pH}$ and service life of up to $168 \mathrm{~h}$; the level of ionic silver is proportional to the concentration of the solution; even at $5 \%$ concentration, the solutions were capable of indicating loss of marginal seal in the composite restorations; the 3-step conventional adhesive system had better performance regarding microleakage in enamel on primary and permanent teeth.

\section{ACKNOWLEDGMENTS}

This study was partially supported by FAPESP (03/12192-0 and 03/10416-8), CNPq (307319/06-7) and PQI/CAPES (00090/03-4).

Walter Luiz Siqueira is a recipient of the CIHR New Investigator Salary Award. 


\section{REFERENCES}

1- Alani AH, Toh CG. Detection of microleakage around denta restorations: a review. Oper Dent. 1997;22(4):173-85.

2- Almeida KG, Scheibe KG, Oliveira $A E$, Alves CM, Costa JF. Influence of human and bovine substrate on the microleakage of two adhesive systems. J Appl Oral Sci. 2009;17(2):92-6.

3- Awliya WY, El-Sahn AM. Leakage pathway of Class V cavities restored with different flowable resin composite restorations. Oper Dent. 2008;33(1):31-6.

4- Bauer JR, Reis A, Loguercio AD, Barroso LP, Grande RH. Effects of aging methods on microleakage of an adhesive system used as a sealant on contaminated surfaces. J Appl Oral Sci. 2005;13(4):37781.

5- Borges MA, Matos IC, Dias KR. Influence of two self-etching primer systems on enamel adhesion. Braz Dent J. 2007;18(2):113-8. 6- Celiberti P, Lussi A. Use of a self-etching adhesive on previously etched intact enamel and its effect on sealant microleakage and tag formation. J Dent. 2005;33(2):163-71.

7- Douglas WH, Fields RP, Fundingsland J. A comparison between the microleakage of direct and indirect composite restorative systems. J Dent. 1989;17(4):184-8.

8- Ernst $\mathrm{CP}$, Kotter $\mathrm{T}$, Victor A, Canbek $\mathrm{K}$, Brandenbusch $\mathrm{M}$, Willershausen $B$. Marginal integrity of self- and total-etching adhesives in two different application protocols. J Adhes Dent. 2004;6(1):25-32.

9- Fernando de Goes M, Montes MA. Evaluation of silver methenamine method for nanoleakage. J Dent. 2004;32(5):391-8.

10- Giachetti L, Scaminaci Russo D, Bambi C, Nieri M, Bertini F. Influence of operator skill on microleakege of total-etch and selfetch bonding systems. J Dent. 2008;36(1):49-53.

11- Gladys S, Van Meerbeek B, Lambrechts P, Vanherle G. Microleakage of adhesive restorative materials. Am J Dent. 2001;14(3):170-6.

12- Gwinnett JA, Tay FR, Pang KM, Wei SH. Comparison of three methods of critical evaluation of microleakage along restorative interfaces. J Prosthet Dent. 1995;74(6):575-85.

13- Hammesfahr PD, Huang CT, Shaffer SE. Microleakage and bond strength of resin restorations with various bonding agents. Dent Mater. 1987;3(4):194-9.

14- Heintze S, Forjanic M, Cavalleri A. Microleakage of Class II restorations with different tracers-comparison with SEM quantitative analysis. J Adhes Dent. 2008;10(4):259-67.

15- Li H, Burrow MF, Tyas MJ. The effect of concentration and $\mathrm{pH}$ of silver nitrate solution on nanoleakage. J Adhes Dent. 2003;5(1):1925.
16- $\mathrm{Li} \mathrm{H}$, Burrow MF, Tyas MJ. The effect of thermocycling regimens on the nanoleakage of dentin bonding systems. Dent Mater. 2002;18(3):189-96.

17- Lopes GC, Franke M, Maia HP. Effect of finishing time and techniques on marginal seal ability of two composite restorative materials. J Prosthet Dent. 2002;88(1):32-6.

18- Neter JK, Nachtsheim CJ, Wasserman W. Applied linear statistical models. $4^{\text {th }}$ ed. Chicago: Irwin; 1996.

19- Pintado MR, Douglas WH. The comparison of microleakage between two different dentin bonding resin systems. Quintessence Int. 1988;19(12):905-7.

20- Reis A, Loguercio AD, Carvalho RM, Grande RH. Durability of resin dentin interfaces: effects of surface moisture and adhesive solvent component. Dent Mater. 2004;20(7):669-76.

21- Sano H, Takatsu T, Ciucchi B, Horner JA, Matthews WG, Pashley $\mathrm{DH}$. Nanoleakage: leakage within the hybrid layer. Oper Dent. 1995;20(1):18-25

22- Silveira de Araújo C, Incerti da Silva T, Ogliari FA, Meireles SS, Piva $E$, Demarco FF. Microleakage of seven adhesive systems in enamel and dentin. J Contemp Dent Pract. 2006;7(5):26-33.

23- Soares CJ, Celiberto L, Dechichi P, Fonseca RB, Martins LR. Marginal integrity and microleakage of direct and indirect composite inlays: SEM and stereomicroscopic evaluation. Braz Oral Res. 2005;19(4):295-301.

24- Swanson TK, Feigal RJ, Tantbirojn D, Hodges JS. Effect of adhesive systems and bevel on enamel margin integrity in primary and permanent teeth. Pediatr Dent. 2008;30(2):134-40.

25- Tay FR, Pashley DH. Water treeing - a potential mechanism for degradation of dentin adhesives. Am J Dent. 2003;16(1):6-12. 26- Taylor MJ, Lynch E. Microleakage. J Dent. 1992;20(1):3-10. 27- Van Meerbeek B, De Munck J, Yoshida Y, Inoue S, Vargas M, Vijay $P$, et al. Buonocore memorial lecture. Adhesion to enamel and dentin: current status and future challenges. Oper Dent. $2003 ; 28(3): 215-35$.

28- Wu W, Cobb EN. A silver staining technique for investigating wear of restorative dental composites. J Biomed Mater Res. $1981 ; 15(3): 343-8$

29- Wu W, Cobb EN, Dermann K, Rupp NW. Detecting margin leakage of dental composite restorations. J Biomed Mater Res. $1983 ; 17(1): 37-43$.

30- Youngson CC, Jones JC, Manogue M, Smith IS. In vitro dentinal penetration by tracers used in microleakage studies. Int Endod J. 1998;31(2):90-9. 